\title{
Anglo-Saxon and Arab Encounters
}

Achraf Idrissi

https://doi.org/10.30608/HJEAS/2021/27/1/17

Stampfl, Tanja. A Century of Encounters: Writing the Other in Arab North Africa. New York: Routledge, 2019. 197 pages. ISBN 9781138363106. Pbk. \$155.

A Century of Encounters showcases Tanja Stampfl's critical engagement with the literature of the Maghreb as it interacts with American and European literary depictions of "Self" and "Other" in twentieth-century Arab North Africa. This study encompasses various literary works written originally in English, as well as translated distinguished novels, whose common themes revolve around the notion of the Encounter between the East and the West. Her selection extends back to the early twentieth century, to the colonial period dealing with Edith Wharton's travelogue In Morocco (1920), and ends with Ahdaf Soueif's The Map of Love (1999), encapsulating a kaleidoscopic history of violent, perturbing, and romantic encounters between the Euro-American and the Arab world. On the one hand, through her proposition of the notion of "Shared Literatures" (137), Stampfl conceptualizes the Encounter as an acute critical lens to problematize economies of gender, race, and national identities as they travel, migrate, cross borders, and interrogate normative cultural traditions. On the other hand, she also inquires the way in which the positionality of the tourist in the postcolonial world is conditioned by neocolonial practices. Drawing upon such theoretical bearings, she believes that the transnational atmosphere that has characterized the twentieth century can facilitate a productive Encounter between different cultures and contribute to the establishment of constructive cross-cultural interactions between the United States, Europe, and Arab North Africa in particular. 
Structurally, the book begins by providing a thorough theoretical framework, evoking some of the leading theorists in literary studies, as well as challenging some of them. The introductory chapter entitled "A World of Encounters" identifies postcolonial literature, travel writing, and feminist literature as the main theoretical building blocks for her criticism. She discusses Edward Said's influence on postcolonial studies eventuating his concept of "overlapping histories" (6), which emphatically reverberates the logic behind her project as a whole. She argues that this Saidian notion "emphasizes a meeting ground between the colonizer and the colonized, a ground which very often seems to be neglected and reduced to either forces of oppression or sites of resistance" (6). Such a ground, she believes, will facilitate a profound redefinition of the Encounter different from the Manichean logic that characterizes the Orientalist and colonial discourse, towards a vision of understanding it as "countering together" and "countering each other"(4). Thus, Stampfl refers to her approach in the introduction as a "humanist perspective" (3). To balance out the theoretical contributions, Stampfl commendably resorts to a few major works from the Arab world. She draws upon Ahdaf Soueif's concept of the mezzaterra, which is reminiscent of Edward Said's "meeting ground." She posits that such an interstitial space is necessarily fragmentary and consequentially an anti-essentialist space where relations between the West and the Arab world are exposed to critical inquiry.

The second chapter creatively demonstrates how Western centrism can be dismantled through psychological properties of fantasy and desire that Stampfl maintains to have characterized the colonial discourse since its very beginnings. It deals with Wharton's In Morocco and E. M. Hull's The Sheik (1919): a travelogue and a novel written at the beginning of the twentieth century, when most of the Arab world was subjugated to colonial rule. Stampfl approaches both works looking for disruptive moments where the hegemony of the colonial discourse is thrown into disarray through notions of gender and nationalism, as well 
as instances of fantasy and desire, hence the Encounter between an authoritative Self and a submissive Other is problematized. It is a subversive strategy that essentially foregrounds the writing of subjectivities that imperial ideology silences or fails to recognize through its hegemonic domination and brutality.

The third and fourth chapters cover the era between 1940 and 1970, embodying what Stampfl identifies as the "tourist era" (52) and its subtle extension into a "neocolonial model" (74). She discusses it as a period when the liberationist spirit penetrated colonized countries, and the world began to witness the crumbling of traditional empires, and their resurrection into economies of relations conditioned by tourism, consumer mentalities, and capitalism. Stampfl accurately identifies this point as marking a transition from confrontations in a colonial context to clashes characterized by consumerism and the aura of "imperial nostalgia" (52). Stampfl offers a reading of Paul Bowles's The Sheltering Sky (1949) focusing on the juxtaposition of Port Moresby and Kit, an American couple journeying in Algeria. Whereas Port's identity is fraught with conflicts between dismissing the ways in which nationality, class, and race reconfigure his sense of Self, simultaneously acting out the national myth of post-WWII America emerging as a world leading power economically and globally extending its influential weight, Kit accepts her state of Otherness in the Algerian context and engages in transformative cross-cultural relationship. Port constructs an imagined Self whose raison d'être is contradictory. While he verbally disassociates with the capitalist America, claiming to be a "citizen of the world" (63), most of his dealings with the natives are conditioned by a consumer mentality. He perceives the Maghrebian locals to be "primarily laboring bodies, whose services he purchases" (63). Two decades later, Patricia Highsmith's The Tremor of Forgery (1969) still reverberates the same dehumanized encounters where the hegemonic Western subject, while internally overwrought by tensions, still reserves and asserts his position, through financial transactions and their economic impact on the local region. 
Stampfl astutely reads such a contradiction as a critique of colonialism and its neo-colonial extension (tourism), highlighting moments when clashes between North African locals and Western characters vocalize slippages that the neo-colonial discourse struggles to silence. For Stampfl, one of the characters that escapes such a contradiction is Kit, whose "imagined Self" coincides with her "lived experience" (66). She recognizes her positionality as the Other in a Muslim country, yet she "engages with Arab characters on a more equal footing" (66), and realizes her own dependence on the locals and vulnerability vis-à-vis Algeria as an unfamiliar setting. Stampfl reads such characteristics as enabling Kit to transcend the colonial and consumer mentality in her contacts with the Arabs, particularly through her sexual encounters. Similarly, the protagonist of The Tremor of Forgery, Howard Ingham also strips away from the garment of "tourist to the traveler," and discloses his "homoerotic male desire" (75) towards Tunisian men.

However, Stampfl seems to have missed the possibility that the inclination of Kit and Ingham towards the natives, which in both novels finally culminates in sexual affairs with them, renders the Arab characters an escapist space for troubled western characters, where they can fulfill their desires. Kit's relationship with Port is "stifling and hierarchical, her encounters with Arab men empower her and increase her self-sufficiency" (67). Stampfl also writes that Kit's acceptance of help from North Africans "while it poses an admission of her dependence on others, signifies the beginning of her agency" (68). The fact that her female agency transpired in a sexual affair with Arab men proves to be ironic, as it clearly embodies the fulfillment of an Orientalist fantasy rather than the actual recognition of a different culture and a human encounter. Similarly, while Howard Ingham disrupts "the European norms of masculinity and heterosexual priority" (75) in the post-Cold War period, he still "aligns with a long tradition of Western Anglo-European and US men who have been gripped by and compelled to respond to and represent the 'perceived relative openness . . of erotic relations 
between men in the Islamicate world"” (78). Kit and Ingham both embody a rebellious spirit towards traditional Western cultural values. However, the manifestation of such rebelliousness still bears the traces of Orientalism where non-normative sexual fantasies of Western characters are projected onto the Arab Other.

Despite sexually engaging with the Arab by consent, the fact that Kit has to dress up as a young man to get access to the so-called Arab lover's room is problematic, especially as it foregrounds the contentious question of homosexuality in a Muslim country. It might be liberating for her, but the occurrence is not as innocent as Stampfl regards it to be. Howard Ingham exploits the Arab Other to process his metaphorical transgression of heterosexual normativity. The emphasis on his writing profession throughout the novel unravels his unsettled position in relation to his sexuality (which is never professed openly in the novel) and Western heterosexual norms, so he projects such internal tensions onto an Arab Muslim country, a gesture that is reminiscent of Orientalist writing.

The following three chapters are connected by their reflection on the experience of Arabs crossing to and living in the West. Stampfl explores Tayeb Saleh's Season of Migration to the North (1966), Ahlam Mosteghanemi's Memory in the Flesh (1993), and Ahdaf Soueif's The Map of Love (1999) in terms of their ability as postcolonial texts to navigate an interstitial space between "Orientalist and Occidentalist discourses" (99), to reverse the gaze and question the "impermeability of one's culture" (99) as characters transgress sexual, racial, and national boundaries. Saleh's and Mosteghanemi's novels interrogate the notion of hybridity and belonging through violent and traumatic cross-cultural encounters, whose effects either eventuate in death or free the body from Orientalist depictions of gender and racial extremities. Both novels evoke the experience of crossing over borders and returning home to find that "outside influences ... have stolen into [the characters'] beliefs, actions, and view of the world" (120), a Utopian spirit. Soueif's The Map of Love fleshes out a utopic world where 
interracial love forms the central theme (146), and transnational Encounters serve as a basis for understanding and coherence. Stampfl cleverly positions this novel as the last to be analyzed, to crystallize her humanist approach and build a solid ground to her proposed notion of a new prism to read "globalized shared literature and history" (173), where categories of Self and Other become transparent and fluid economies of mobile relations and Encounters. Stampfl acutely demonstrates that the globalized transnational context of the modern world no longer holds for the traditional reading of "the Self and the Other . . . as oppositional categories" (174). Focus should rather be on instances where "the Self can function as the Other" (174) and on moments that stress "shared explorations [to] reveal shared histories and aid in finding out about the Self by studying the Other" (180). Stampfl's accentuation of the interconnectedness of human experience renders this book as much intelligible to researchers interested in postcolonial studies, as it is to those interested in cross-cultural dialogue, literary studies, and essentially literature, as it offers a fresh critique of previous interpretations and a new angle to read world literature. 